\title{
Neuropathology of the brainstem and spinal cord in end stage rheumatoid arthritis: implications for treatment
}

\author{
Fraser C Henderson, Jennian F Geddes, H Alan Crockard
}

\begin{abstract}
Objective-To study the detailed histopathological changes in the brainstem and spinal cord in nine patients with severe end stage rheumatoid arthritis, all with clinical myelopathy and craniocervical compression.

Methods-At necropsy the sites of bony pathology were related exactly to cord segments and histological changes, and correlated with clinical and radiological findings.

Results-Cranial nerve and brainstem pathology was rare. In addition to the obvious craniocervical compression, there were widespread subaxial changes in the spinal cord. Pathology was localised primarily to the dorsal white matter and there was no evidence of vasculitis or ischaemic changes.

Conclusions-Myelopathy in rheumatoid arthritis is probably caused by the effects of compression, stretch, and movement, not ischaemia. The additional subaxial compression may be an important component in the clinical picture, and may explain why craniocervical decompression alone may not alleviate neurological signs.
\end{abstract}

Department of Neurosurgery, National Naval

Medical Center,

Bethesda,

MD 20814-5011, USA

F C Henderson

Department of

Morbid Anatomy,

London Hospital

Medical College,

Turner Street,

London E1 1BB,

United Kingdom

J F Geddes

Department of

Surgical Neurology,

The National Hospital

for Neurology and

Neurosurgery,

Queen Square

London WC1N 3BG,

United Kingdom

H A Crockard

Correspondence to:

Dr Crockard.

Accepted for publication 20 May 1993
(Ann Rheum Dis 1993; 52: 629-637)

Rheumatoid arthritis is a systemic disease affecting the cervical spine in $16-88 \%$ of patients. ${ }^{1-6}$ Progressive subluxation is common, ${ }^{7-9}$ associated with increasing compression of the spinal cord and brain stem, ${ }^{510-15}$ and may cause clinical myelopathy and even sudden death. ${ }^{316} 17$ Despite these clinical effects, the pathophysiology and histopathology of cord and brain stem injury due to this type of compression are poorly understood, and there are only two studies available in which changes in the cord are described in any detail. ${ }^{418}$ As part of our wider study of cervical myelopathy in over 250 patients with rheumatoid arthritis we performed a detailed histopathological study of the spinal cord and brain stem in nine patients, and compared features. the findings with clinical and radiological

\section{Methods}

This study includes nine patients with seropositive rheumatoid arthritis (eight women, one man) from our ongoing prospective study, who underwent necropsy at the National Hospitals for Neurology and Neurosurgery between 1987 and 1991. All patients were evaluated by rheumatologists, a neurosurgeon (HAC), two neuroradiologists, a physiotherapist, and a research nurse. The clinical assessment included a full neurological examination and a detailed questionnaire about neurological symptoms. In addition, all patients were graded according to Ranawat et $a l^{19}$ and Steinbrocker et al. ${ }^{20}$ The radiological assessment included plain lateral films of the cervical spine and high definition computed myelotomography with multiplanar reformatting. ${ }^{21}$ All operations were carried out by or under the direction of the same surgeon (HAC). Necropsies were performed by or under the supervision of the same neuropathologist (JFG). The necropsy technique used to remove the foramen magnum and cervical spine with the cord and medulla intact has been described previously. ${ }^{22}$

Multiple transverse blocks of the cord were taken, and sections stained with haematoxylin and eosin, luxol fast blue, Woelche, Heidenhain, and modified Bielchowsky stains. Reticulin, Nissl, van Gieson, periodic acidSchiff, and glial fibrillary acidic protein (Dako; $1: 400)$ stains were performed on selected blocks.

\section{Pre-operative results}

CLINICAL FINDINGS

The table gives a summary of the principal clinical details.

The nine patients presented in this study were all white with longstanding seropositive rheumatoid arthritis, aged 47-72 years (average age 60 years, median age 64 years). The only man in the study was the youngest patient.

All patients had been treated with steroids during the course of the disease, three with gold and one with the addition of azathioprine. One other patient had azathioprine without gold. 
Six of the nine patients presented with rapid neurological deterioration over three to 32 weeks (average 11 weeks, median 12 weeks). Patients 1, 6, and 9 had longstanding myelopathy.

Symptoms on presentation included neck pain (8/9), occipital neuralgia (8/9), hand numbness (7/9), weakness-usually arms weaker than legs-(8/9), incontinence or urinary retention (4/9), dysphagia (3/9), and dyspnoea (2/9).

Cranial nerve examination was normal in all patients. A corneal ulcer was found in patient 5 , but the trigeminal nerve function was normal.

Somatosensory evoked potentials and motor evoked potentials were attempted in six patients and results obtained in four. Sleep studies of respiratory function were obtained in three. These are the subject of another study.

\section{RADIOLOGICAL FINDINGS}

The atlantodental interval varied from 1 to $11 \mathrm{~mm}$ (average $4.7 \mathrm{~mm}$, median $3 \mathrm{~mm}$ ). There was, however, marked vertical subluxation of the axis in all nine patients, measuring 9-26 mm using the technique described by Redlung-Johnell and Pettersson. ${ }^{23}$ The tip of the odontoid process impinged on the upper medulla in patients 1,8 , and 9. Prominent backward tilting of the dens was present in patients 2 and 5 with compression of the medulla and upper cord at the level of $\mathrm{C} 1$. Patient 6 had medullospinal compression only during flexion (fig 1). The remaining patients showed cord compression by the dens at the C1 level. Major posterior compression from the neural arch of $\mathrm{C} 1$ was apparent only in patient 7.

Subaxial bony changes were present in $8 / 9$ patients. Only patient 6 had a normal subaxial spine (see table).
OPERATIVE FINDINGS AND COMPLICATIONS All patients were referred for surgery because of craniocervical junction compression or instability, or both, and, according to criteria outlined elsewhere, ${ }^{24}$ had transoral odontoidectomy and decompression of the dura. Under the same anaesthesia a posterior occipitocervical stabilisation with a Ransford loop and sublaminar wire fixation was carried out. One patient (patient 5) was so ill because of respiratory insufficiency that an operation was never considered. None of the patients in this study required only posterior stabilisation without anterior decompression. Thus our patients had the most severe atlantoaxial compression.

In three patients there were problems related to the passage of sublaminar wires. Two were weaker after the operation (patients 1 and 4), a third patient (patient 8) improved initially, but was readmitted six weeks later as a quadriplegic; radiographs revealed 'cut out' of the sublaminar wire at several levels and a severe subaxial cord compression at C5/6.

Other causes of death included haemorrhage (patients 2 and 7), abscess (patient 6), pneumomediastinitis (patient 3), and myocardial infarction (patient 9).

\section{GROSS PATHOLOGICAL FINDINGS}

The vertebral artery was patent in all specimens. In seven of the eight patients in whom an operation was performed, the odontoid process and variable amounts of $\mathrm{C} 2$ had been resected. In five of the nine patients the upper cervical cord was compressed and flattened by the residual body of $\mathrm{C} 2$, and the anteroposterior diameter of the upper two cervical segments was correspondingly much reduced. In patient 1 the arch of $\mathrm{C} 1$ was assimilated to the occiput. In patient 7 the foramen magnum diameter was reduced. In three patients there was a markedly reduced
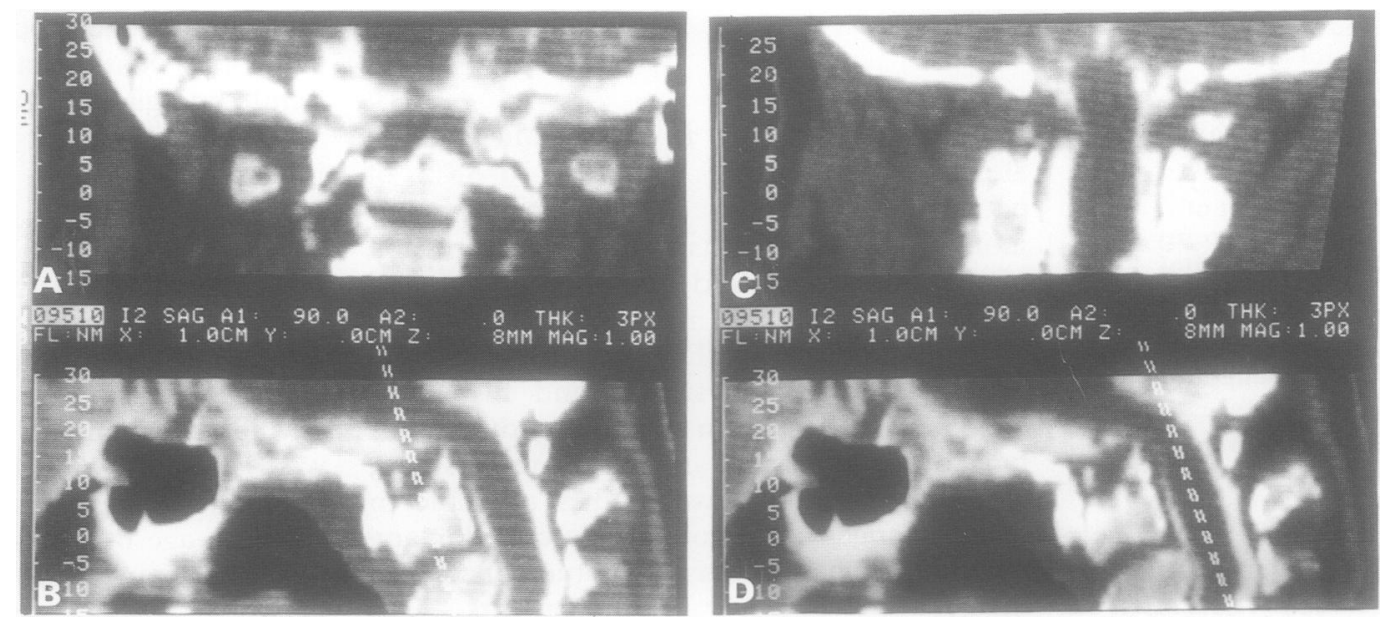

Figure 1 Coronal and sagittal reformatting through the craniocervical junction in patient 6 after myelotomography. The broken line indicates the plane of coronal reformat on the sagitally reformatted image. $(A)$ The odontoid process and lateral masses of the atlas and axis are eroded. (B) The brainstem is angulated and compressed by the subluxed axis. There is also mild neuraxial deformity caused by subluxation of the axis on the body of $C 3$. (C) The neuraxis is compressed on the right by granulation tissue. (D) The neuraxis has 'telescoped' through the ring of $C 1$. The posterior ring of the atlas is tilted upward, and the anterior arch tilted downward causing a 'pseudo-reduction' of the atlantodental interval. 
Summary of clinical and radiological findings

\begin{tabular}{|c|c|c|c|c|c|c|c|c|c|}
\hline $\begin{array}{l}\text { Patient } \\
\text { No }\end{array}$ & $\begin{array}{l}\text { Age } \\
\text { (years)/ } \\
\text { sex }\end{array}$ & $\begin{array}{l}\text { Duration of } \\
\text { disease (years)/ } \\
\text { drugs received }\end{array}$ & $\begin{array}{l}\text { Findings before } \\
\text { operation }\end{array}$ & $\begin{array}{l}\text { Ranawat/ } \\
\text { American } \\
\text { Rheumatism } \\
\text { Association } \\
\text { grades }\end{array}$ & $\begin{array}{l}\text { mm Vertical } \\
\text { axial } \\
\text { subluxation/ } \\
\text { ADI }(m m) / \\
C S A \text { cord } \\
\left(m^{2}\right)^{\star}\end{array}$ & Subaxial changes & $\begin{array}{l}\text { Operative } \\
\text { findings }\end{array}$ & $\begin{array}{l}\text { Findings after } \\
\text { operation }\end{array}$ & $\begin{array}{l}\text { Time from } \\
\text { operation } \\
\text { to death } \\
\text { (days) }\end{array}$ \\
\hline 1 & $47 / \mathrm{M}$ & 25/gold & $\begin{array}{l}\text { Normoreflexia, } \\
\text { quadriparesis, } \\
\text { normal sensation }\end{array}$ & $\mathrm{IIIb} / 4$ & $23 / 11 / 60$ & $\begin{array}{l}\text { Fibrous, } \\
\text { ankylosis C2-C6 }\end{array}$ & $\begin{array}{l}\text { Fibrous pannus, } \\
\mathrm{C} 1 \text { fracture, } \\
\text { anterior } \mathrm{Cl} \\
\text { fused to clivus }\end{array}$ & $\begin{array}{l}\text { Neurologically } \\
\text { unchanged, } \\
\text { tetraplegic on day } 2\end{array}$ & 56 \\
\hline 2 & $58 / \mathrm{F}$ & 11 & $\begin{array}{l}\text { Spastic quadriparesis, } \\
\text { suspended } \\
\text { sensory loss }\end{array}$ & $\mathrm{III} / 3$ & $17 / 1 / 40$ & $\begin{array}{l}\text { Subluxation C6-7 } \\
\text { with stenosis }\end{array}$ & Florid pannus & $\begin{array}{l}\text { Dysphagia, walking, } \\
\text { day } 29 \text { haemoptysis, } \\
\text { metabolic } \\
\text { disturbance }\end{array}$ & 30 \\
\hline 3 & $72 / \mathrm{F}$ & 16 & $\begin{array}{l}\text { Incontinence, } \\
\text { spastic quadriparesis, } \\
\text { weak triceps, } \\
\text { dissociated } \\
\text { sensory loss, } \\
\text { L'Hermittes sign }\end{array}$ & $\mathrm{IIIb} / 4$ & $9 / 6 / 36$ & $\begin{array}{l}\text { Severe spondylosis, } \\
\text { C5-6 ventral } \\
\text { osseous bar }\end{array}$ & $\begin{array}{l}\text { Fibrous pannus, } \\
\mathrm{C} 1 \text { fused to peg }\end{array}$ & $\begin{array}{l}\text { Laryngeal oedema, } \\
\text { tracheal perforation, } \\
\text { mediastinitis }\end{array}$ & 11 \\
\hline 4 & $70 / \mathrm{F}$ & 55 & $\begin{array}{l}\text { Urinary retention, } \\
\text { spastic quadriparesis, } \\
\text { sensory level C7 }\end{array}$ & $\mathrm{IIIb} / 4$ & $12 / 11 / 40$ & $\begin{array}{l}\text { C5-6 subluxation, } \\
\text { severe kyphosis }\left(45^{\circ}\right) \text {, } \\
\text { pannus, } \\
\text { myelographic } \\
\text { block at C7 }\end{array}$ & Florid pannus & $\begin{array}{l}\text { Left side weaker, } \\
\text { respiratory arrest, } \\
\text { SIADH }\end{array}$ & 11 \\
\hline 5 & $54 / \mathrm{F}$ & 16/azathioprine & $\begin{array}{l}\text { Dyspnoea, dysphagia, } \\
\text { corneal ulcer, } \\
\text { incontinence, } \\
\text { spastic quadriparesis, } \\
\text { hypoaesthesia } \\
\text { below C4, } \\
\text { incontinence, } \\
\text { anaesthetic C4 down }\end{array}$ & $\mathrm{IIIb} / 4$ & $26 / 1$ & $\begin{array}{l}\text { Subluxation C4 on } \\
\text { C5 with ventral } \\
\text { osseous bar }\end{array}$ & \multicolumn{2}{|c|}{$\begin{array}{l}\text { No operation performed } \\
\text { (severe asthma) }\end{array}$} & $\begin{array}{l}31 \text { days after } \\
\text { admission }\end{array}$ \\
\hline 6 & $63 / \mathrm{F}$ & 25/gold & $\begin{array}{l}\text { Bilateral deltoids and } \\
\text { triceps weakness, } \\
\text { ankle clonus }\end{array}$ & $\mathrm{III} a / 3$ & $22 / 0 / 81$ & None & Fibrous pannus & $\begin{array}{l}\text { Neurologically } \\
\text { unchanged } \\
\text { until day } 28, \\
\text { abscess C5-6, } \\
\text { quadriplegic }\end{array}$ & 39 \\
\hline 7 & $64 / \mathrm{F}$ & 25 & $\begin{array}{l}\text { Dysphagia, } \\
\text { urine retention, } \\
\text { spastic quadriparesis, } \\
\text { hemianaesthesia }\end{array}$ & $\mathrm{IIIb} / 4$ & $19 / 17 / 35$ & Subluxation C3-4 & Florid pannus & $\begin{array}{l}\text { Day } 7 \text { posterior } \\
\text { pharyngeal } \\
\text { haemorrhage }\end{array}$ & 7 \\
\hline 8 & $64 / \mathrm{F}$ & $\begin{array}{l}\text { 8/gold and } \\
\text { azathioprine }\end{array}$ & $\begin{array}{l}\text { Dyspnoea, } \\
\text { mild leg weakness, } \\
\text { normal sensation }\end{array}$ & $\mathrm{IV} / 3$ & $24 / 3 / 68$ & $\begin{array}{l}\text { Staircase spine } \mathrm{C} 2-\mathrm{T} 1 \text {, } \\
\text { marked subluxation } \\
\mathrm{C} 5-6\end{array}$ & $\begin{array}{l}\text { Fibrous pannus, } \\
\text { wire pulled } \\
\text { through laminae }\end{array}$ & $\begin{array}{l}\text { Weak right } \\
\text { arm day } 42 \text {, } \\
\text { quadriplegic with } \\
\text { myelographic } \\
\text { block C5-6 }\end{array}$ & 49 \\
\hline 9 & $68 / \mathrm{F}$ & 32 & $\begin{array}{l}\text { Dysphagia, } \\
\text { spastic quadriparesis, } \\
\text { diffuse sensory loss }\end{array}$ & $\mathrm{IIIb} / 4$ & $21 / 5 / 29$ & $\begin{array}{l}\text { Subluxation C3-4, } \\
\text { minor subluxation } \\
\text { C5-6, C6-7, C8-T1 }\end{array}$ & ?Pannus & $\begin{array}{l}\text { Lower } \\
\text { gastrointestinal } \\
\text { haemorrhage, } \\
\text { cardiac arrest }\end{array}$ & 18 \\
\hline
\end{tabular}

${ }^{\star} \mathrm{ADI}=$ atlantodental interval; $\mathrm{CSA}=$ cross sectional area of spine at point of maximum compression (at foramen magnum) with neck in extension; SIADH=syndrome of inappropriate centidiuretic hormone.

clivoaxial angle with concomitant kyphus or flexion of the medulla (patients 6, 8, and 9).

Significant subaxial pathology was present in eight spines in keeping with the radiological findings: fibrous ankylosis, disc erosion with subluxation (often at multiple levels), vertebral body collapse, and ventral bars (hard discs). Figure 2 shows the appearances in a typical case (patient 8 ) once the fixed spine had been hemisected, and the cord replaced in the spinal canal. In two patients the Ransford loop sublaminar wires had partially cut through the osteoporotic bone (patients 2 and 8 ).

\section{NEUROPATHOLOGY}

Figure 3 summarises the histological findings in four representative patients.

With the exception of gliosis of the trigeminal nucleus (patient 8), and mild unilateral changes in the hypoglossal and dorsal motor nuclei of the vagus (patient 2), the cranial nerve nuclei were normal.

Where the compression was most severe, the cord was fragmented and necrotic. At the levels where the cord was less severely compressed, the pathology was localised principally to the dorsal white matter, which was oedematous and showed axonal disruption. In one cord (patient 1) a circumscribed area of columnar necrosis ('pencillar heterotopia') was seen in the ventral part of the dorsal columns, extending some way below the site of maximum compression, with ependymal cells and a degenerated anterior horn cell from a higher cord segment being found in necrotic debris dorsal to the central canal in the lowest segment, suggesting that the necrotic debris had been mechanically extruded away from the site of compression.

Milder degrees of compression produced milder changes, notably oedema, axonal and myelin loss. The most consistent changes were in the dorsal columns, the cuneate fascicle usually being more severely affected than the gracile. At one level in one cord (patient 5) the anterior horns were necrotic; otherwise the only histological change seen in the grey matter was that of anterior horn cell chromatolysis. Although it was present at several levels in eight of the nine cords, this phenomenon was variable; in any one section from one cell to several cells were chromatolytic. There was no anterior horn cell loss. 


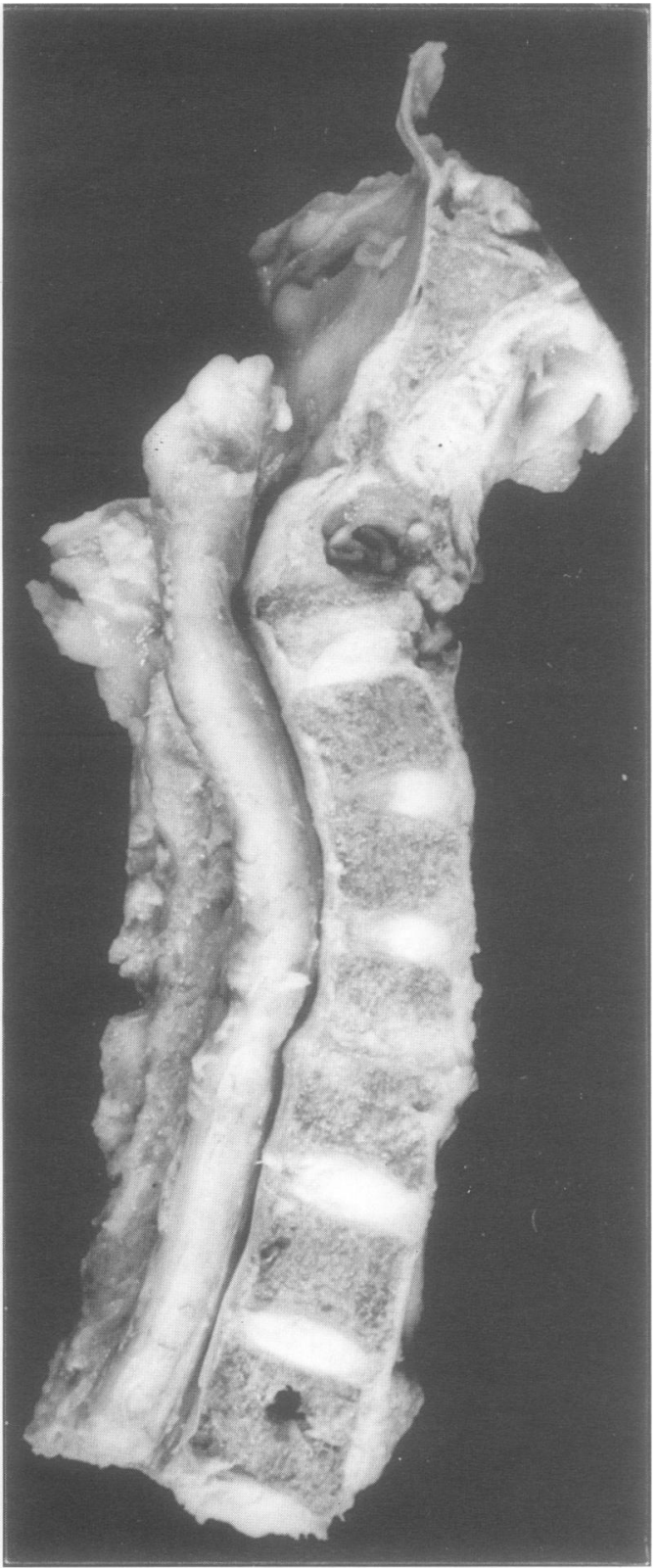

Figure 2 Patient 8. The hemisected cervical spine with the cervical cord replaced in the canal. The odontoid process has been resected. There is cervical stenosis at most levels. The C3-4 and C4-5 discs are partly haemorrhagic. The C5-6 disc was obliterated, and C5 was mobile on C6, producing cord compression. Lesser degrees of subluxation were present at the C2-3 and C4-5 level. The hole in the body of T1 has been made for reference purposes.

In all the cords, the pia-arachnoid was focally thickened at points of compression with chronic inflammation in several instances. There was hyalinisation of intrameduallary arterioles. No evidence of vasculitis or vascular thrombosis was seen in any patient, and apart from the grey matter infarction in patient 5 , there were no changes that might be interpreted as ischaemic.

\section{Discussion}

NEUROPATHOLOGY

Ours is the largest study of the neuropathology of the brain stem and spinal cord in rheumatoid patients; only three similar cases have previously been reported in any detail. ${ }^{4} 18$ Although our patients clearly had exceptionally severe end stage disease, requiring surgical intervention, we consider that our clinical and pathological findings throw light on the pathogenesis of cord damage in rheumatoid arthritis. The histopathological changes were localised principally to the dorsal white matter of the cord, and included oedema, axonal swellings or balloons (fig 4), and necrosis. The localisation of pathology in the dorsal half of the cord was, at first sight, surprising given that the compression was ventral in most patients, but this phenomenon has been demonstrated by Breig, ${ }^{25}$ who in a series of careful and detailed cadaver experiments, showed that a ventral deforming force caused tearing and fissure formation in the dorsal half of the cord.

Another common finding was of central chromatolysis of the ventral horn cells at most cervical levels. We believe this to have resulted from mechanical injury to the axons at the root level, although other aetiologies have been suggested in experimental work. ${ }^{26}$

Other workers have noted the same selective injury of the cuneate fascicles with relative sparing of the gracile fascicles in studies of atlantoaxial subluxation, cervical spondylosis, rheumatoid arthritis, and cervical radicular disease. ${ }^{418}{ }^{27-31}$ This selective injury is not unique to rheumatoid arthritis. Nevertheless, no-one has yet offered an explanation as to why the cuneate fascicle should, in these disorders, suffer more injury than the gracile fascicle.

Could the changes we observed have been the result of surgical trauma? Trauma to the spinal cord typically results in central cord injury, red cell extravasation or frank haemorrhage, hyperaemia, and cellular reaction with the accumulation of polymorphs and later lymphocytes. ${ }^{32-36}$ None of our findings remotely resembles these descriptions and thus we are disinclined to attribute the findings to the operation.

PATHOLOGICAL MECHANISMS

We have considered various aetiologies to explain the preponderance of dorsal pathology, the selective injury of the cuneate fascicles, and the widespread central chromatolysis of ventral grey neurones. Some of the theories are considered in the following.

\section{Vascular}

Compression or disease of the vertebral and anterior spinal arteries are often cited as aetiological factors to spinal cord pathology in rheumatoid and other diseases. ${ }^{4} 183137-39$ Others have implicated intraforaminal compression of important medullary feeding vessels. ${ }^{40-45}$ We observed no changes of acute or chronic ischaemia in the cord and no major extramedullary vessel compression or thrombosis. ${ }^{46-49}$

Vasculitis is characteristic of rheumatoid arthritis and affects the small and medium sized arterioles of the peripheral nerves of the upper arm and mid thigh, causing inflammatory epineurial disease in $93 \%$ of rheumatoid patients ${ }^{50}$ with resulting nerve fibre changes and ganglion cell loss. ${ }^{51}$ It is, however, rare in the spinal cord, ${ }^{50}$ and was not seen in any of our patients. 
Case 3

R

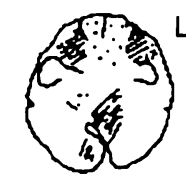

C1

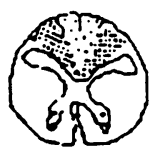

C1-2

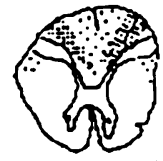

C3

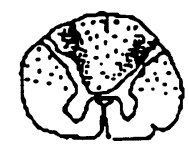

C4
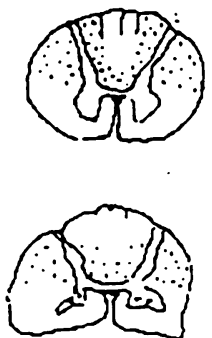

Case 5

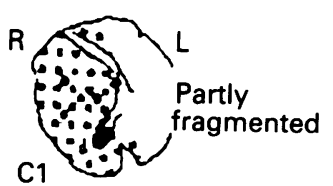

C1
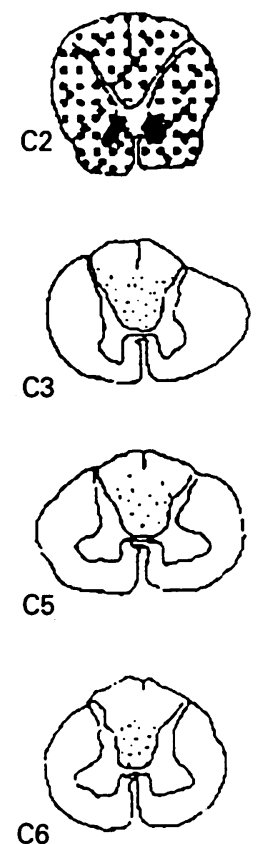

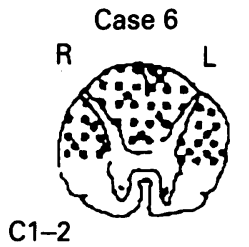

C1-2
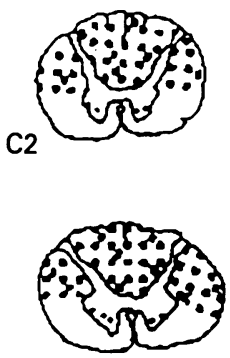

C3
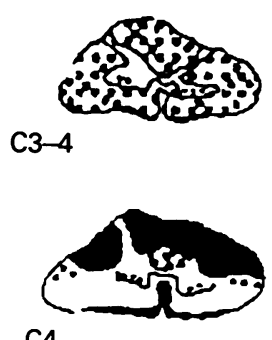

C4

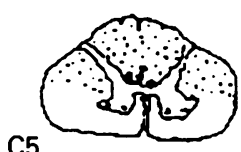

Case 8
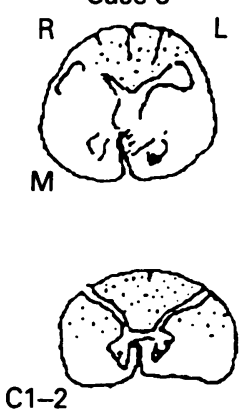

C3
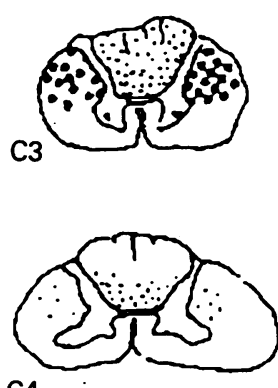

C4

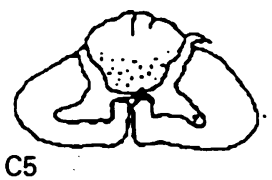

C5

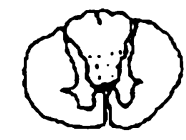

C6

Figure 3 Principal neuropathological findings in patients 3, 5, 6, and 8, mapped onto tracings of cord sections. Solid shading (black) denotes necrosis, coarse stippling axonal swellings, and fine dots oedema. The shading in the cuneate fascicle in patient 3 is Wallerian degeneration. Crosses in the anterior horns represent chromatolytic neurones.

Severe hyalinosis of intramedullary arterioles may cause ischaemia of the cord. The moderate hyalinosis seen in this necropsy series, however, was consistent with senile involutionary change. ${ }^{52}$ Hyalinosis increases with age, and is negatively associated with arteriosclerosis. ${ }^{53}$ Arteriosclerotic myelopathy, characterised by focal rarefactive necrosis primarily in the grey matter, atrophy of neurones, gliosis, and spongiform degeneration ${ }^{49} 53$ was significantly absent in this necropsy series. Indeed, the incidence of spinal arteriosclerosis is low, ${ }^{49}$ even in the presence of cerebrovascular changes. ${ }^{53}$

Abnormalities of venous drainage have been implicated in cervical myelopathy. ${ }^{54-57}$ Although mild venous congestion was noted in four of our patients, there was no evidence of venous thrombosis or occlusion, no haemorrhagic change in the ventral grey matter and, except for the pencillar heterotopia in one patient, no central cord lesion.

Intermittent cord ischaemia may result from systemic atherosclerotic changes, ${ }^{49} 53$ and spinal cord ischaemia compromises the ability of the cord to tolerate compression. ${ }^{45} 58$ Prolonged hypotension is known to provoke central necrosis of the cord. ${ }^{36}$ Could intraoperative ischaemia have produced some of the pathology observed in this series? Again, the absence of central necrosis and of grey matter change argues against intraoperative hypotension being a factor.

Although clearly some degree of ischaemia occurs in the presence of any mechanical deformation of the spinal cord or brain stem, there was no histological evidence of it in this series of patients with severe end stage rheumatoid arthritis. Thus we consider ischaemia unlikely as a primary pathological mechanism.

\section{Neurotoxicity}

Rarely, gold has neurological side effects, including acute, predominantly distal, symmetrical, mixed sensory, and motor polyneuropathy. ${ }^{59}$ A Guillain-Barré pattern of demyelination has been described. ${ }^{60}$ Azathioprine has almost no side effects. It is improbable, therefore, that the white matter changes we have noted were pharmacologically induced.

\section{Stretch and motion}

The cord lengthens and becomes thinner on flexion of the neck, and shortens and thickens on extension. ${ }^{4361}$ Between full extension and full flexion the contour of the dorsal canal increases up to $5 \mathrm{~cm} .{ }^{62}$ Through the dentate ligaments this increased excursion of the spine imparts a stretching force to the cord. ${ }^{63}$ The amount of stretch is surprisingly great: $1.3 \mathrm{~cm}$ 


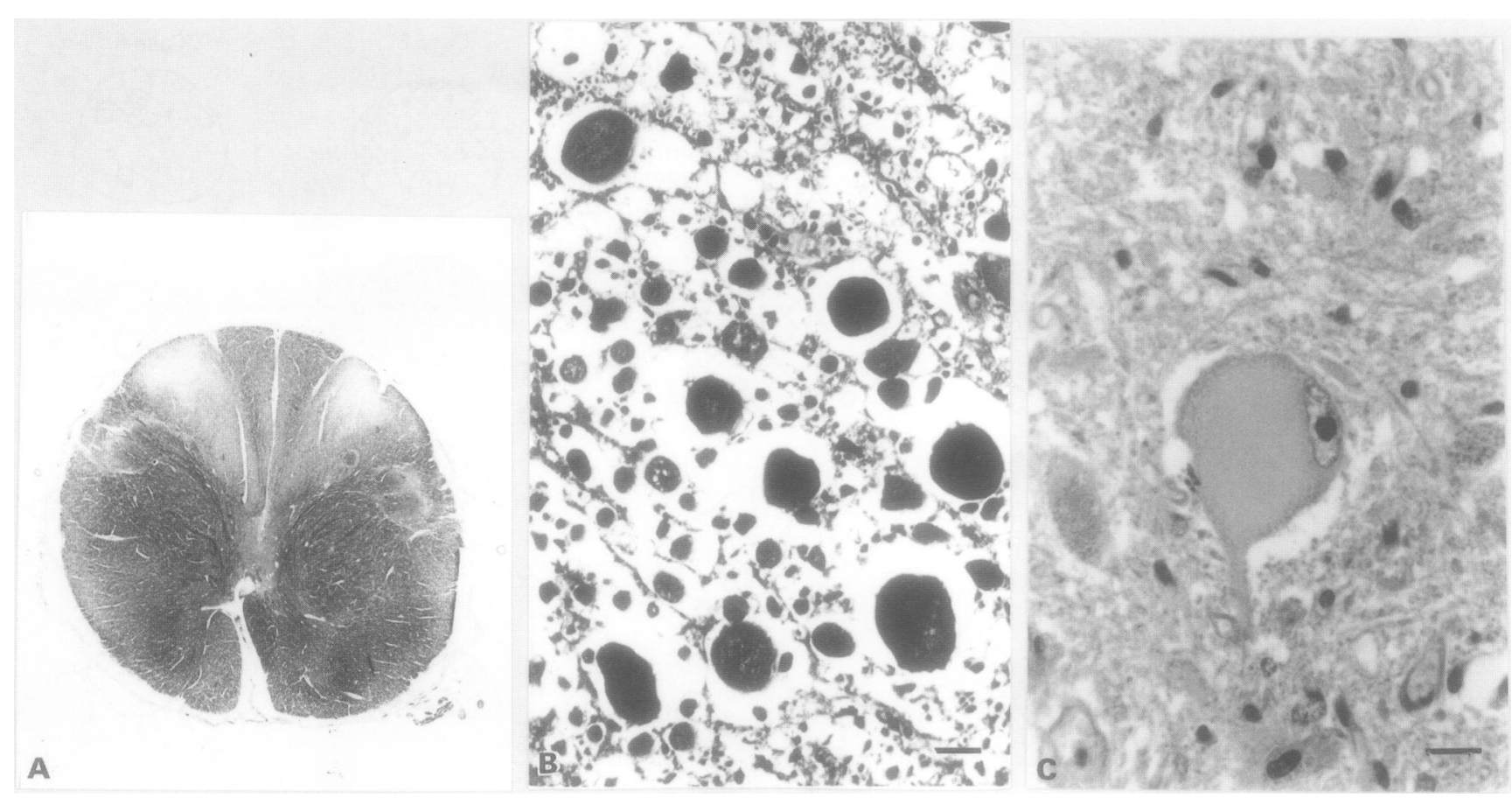

Figure 4 Pathological changes seen in many of the cords. (A) Cross section of the rostral part of the first cervical segment, showing long tract degeneration in the cuneate fascicle (patient 3, Woelche). (B) Axonal swellings at the level of compression (patient 6, Bielschowsky silver impregnation, bar $=20 \mu \mathrm{m}$ ). (C) A chromatolytic anterior horn cell (patient 8 , haematoxylin and eosin, bar $=20 \mu \mathrm{m}$ ).

in cadaver studies. ${ }^{64}$ Cord elongation, in primates at least, occurs maximally at levels where cord motion is greatest-namely, the lower cervical levels. ${ }^{65}$ In human studies, Reid $^{66}$ found only $1 \mathrm{~mm}$ of movement at the C5 level, but $18 \mathrm{~mm}$ of cord movement at the C8 to T3 levels during flexion and extension. Change in length of the cervical canal is normally accompanied by stretching of the dura and spinal cord and movement of the cord within the dura, although this is limited by the dural root sleeves and the dentate ligaments respectively. ${ }^{64}{ }^{66}$ Marked leptomeningeal fibrosis such as we observed may tether nerve roots as they enter the neural foramina, ${ }^{40} 45$ making them more susceptible to trauma ${ }^{30}$ and stretching injury. Furthermore, tethering of the dura to the posterior longitudinal ligament ${ }^{27} 30$ results in variability of dural sac tension in the elderly. ${ }^{66}$ Meningeal tethering may thus impart additional local shear and stress forces on the spinal cord and roots, with resultant axon injury, manifest histologically by chromatolysis and-in time-Wallerian degeneration in the dorsal columns. The presence of a mass ventral to the cord, such as a subluxed dens or spondylotic bar, may increase further the excursion of the spinal cord, thus generating increased axial tension along the neuraxis..$^{25} 63$ Motion may cause repeated trauma over spondylotic protrusions causing myeloradiculopathy, ${ }^{30} 616264-69$ and in our patients there was a great deal of subaxial spondylosis with associated histopathological changes.

\section{Compression}

Although stretch and motion contribute to the final pathology, we have considered compression at the craniocervical junction and subaxial sites to be the principal pathological factor in these patients, though we cannot exclude completely some ischaemia. For the most part, the compression was ventral to the cord. At the foramen magnum, necrosis of the dorsal two thirds of the cord in the first two patients was reasonably explained by the posterior dislocation of the axis. In all but the one patient who did not have an operation (patient 5), compression by the odontoid process was the main cause of cord injury. In all of these, the territory of the anterior spinal artery was spared. Similarly, in the subaxial levels, compression appeared to be responsible for the observed pathology. Dorsal necrosis at the C4 level in patient 6 was probably secondary to a ventral mass - an abscess within the posterior longitudinal ligament. Sparing of the territory of the anterior spinal artery and the absence of ischaemic neuronal changes is against the hypothesis that dynamic compression of the anterior spinal artery was significant. $^{70}$

Cord pathology was always related to compression from degenerative spinal changes: a C6-7 subluxation (patient 2), a ventral osseous bar at C5-6 (patient 3) and at C3-4 (patient 7), a C5-6 kyphosis (patient 4), and staircase spines (patients 8 and 9). Interestingly, the patient presenting with the least neurological deficit (patient 6) had no subaxial spinal changes before the operation; spinal cord pathology after the operation was, however, related to compression from the abscess. Thus compression was present in all patients with cord pathology.

The extent of compression at the subaxial levels and the related neurological deficits have previously been insufficiently emphasised. Again, the effects of compression are increased with traction. ${ }^{25} 69$ Subaxial bone changes occur late in only $20-40 \%$ of rheumatoid spines. $5121518 \quad 71-75$ 
CLINICAL FINDINGS

We found no evidence before the operations of cranial nerve palsy, nystagmus, or internuclear ophthalmoplegia in any of the nine patients in this series. The absence of cranial nerve findings in this series and our other study ${ }^{76}$ is at variance with other series. ${ }^{4} 51012727778 \mathrm{We}$ consider that dysphagia in our patients was due to fixed flexion of the neck, xerostomia, or cricoarytenoid arthritis. ${ }^{79}$ There was only one cranial nerve deficit in this series, and that occurred after the operation (patient 2). In two other series of rheumatoid patients ${ }^{9}$ and congenital atlantoaxial subluxation, ${ }^{31}$ no cranial nerve nuclei changes were noted.

Although there were no major areas of brainstem damage, there may be ultrastructural changes which we did not observe. Subclinical problems such as sleep disturbances do occur in these patients. Howard R S, Henderson F, Hirsch N P, et al (unpublished data) have shown that even in the rheumatoid patient who does not report symptoms there may be central alterations in the respiratory pattern, which may be due to dorsal and dorsolateral column injury.

\section{RADIOLOGICAL FINDINGS}

Atlantoaxial subluxation due to ligament laxity is the most common cervical spine deformity in rheumatoid arthritis. The incidence varies between 25 and $71 \%$ of rheumatoid patients ${ }^{7} 15$ and was present in seven of our nine patients. Approximately $27 \%$ of patients with atlantoaxial subluxation show radiological progression. ${ }^{9}$ Basilar invagination or vertical subluxation of the dens follows atlantoaxial subluxation in $13 \%$ of patients, ${ }^{1}$ and occurs due to erosion of the lateral masses (primarily of the axis) late in the disease process. ${ }^{12}{ }^{13}$ Vertical subluxation, unlike atlantoaxial subluxation, is related to the age of the patient and the duration of the disease. ${ }^{9}$ The average vertical subluxation in this series was $19 \mathrm{~mm}$ (range 9-26 mm). Vertical subluxation causes a pseudoreduction in the atlantodental inter$\mathrm{val}$, and may in fact signal the onset of vertical subluxation of the dens. ${ }^{18912}$ Interpretation of the atlantodental interval must therefore be made in conjunction with measurement of the vertical axial subluxation. It is clear, however, that this bony abnormality is only one aspect of the disease process.

Another factor we studied was the cross sectional area of the spinal cord at the point of maximum compression and the degree of neurological disability. We noted marked decreases in cord cross sectional area in six patients. In general terms our most severely affected patients had the greatest reduction in cord cross sectional area. This is consistent with the finding that cord cross sectional area is predictive of surgical outcome, ${ }^{80}$ and that myelopathy due to repeated microtrauma, such as occurs with undetected odontoid fractures, increases with time. ${ }^{81}$ Chronic cord compression has been shown to cause flattening of the cord, ${ }^{61}$ which is presumably due to demyelination. ${ }^{82}{ }^{83}$ The ability of the nerves to conduct in the peripheral nervous system with only $3 \%$ of the normal myelin thickness ${ }^{84}$ would explain why there is no consistent relation between cross sectional area and clinical disability. ${ }^{61}$

\section{SURGICAL COMPLICATIONS}

There are many lessons to be learnt from our experience, beginning with the degree of disability. Most were Ranawat IIIb and, in our wider study, it is this group that has the greatest mortality and morbidity. Indeed, most of our deaths after the operation presented in this disability category, ${ }^{24}$ and most of the survivors did not achieve self caring status after the operation. Is it poor selection for an operation, or too late referral? Secondly, although all had longstanding disease, their neurological deterioration was rapid (between three and 32 weeks). The question arises as to how best to manage these patients: frequent outpatient assessment, or pre-emptive surgery while they are still comparatively fit?

There are also technical lessons to be learnt, such as the importance of adequate decompression, and in two patients (patients 1 and 8 ) the anterior surgery was inadequate. Sublaminar wire passage for posterior fixation is hazardous, particularly where there is cord compression $^{85}{ }^{86}$; it is hoped that the new stainless steel and titanium cables (Sof'wire, Codman and Shurtleff, Randolph, MA, USA) will cause less intradural damage. Pharyngeal wound infection has occurred in $2 \cdot 1 \%$ of all our transoral operations. The delayed haemorrhages and abscesses are considered to be due to infection. Although tragic when it occurs, it is much less than might have been expected in such ill patients and, in our opinion, less of a hazard than posterior fusion alone in the presence of anterior compression.

\section{Conclusions}

The pathological findings in our series of patients suggest that: (a) cranial nerve and brain stem pathology is uncommon; (b) subaxial degenerative changes of the cervical spine often occur in end stage rheumatoid disease; (c) cord pathology may be caused by subaxial degeneration; $(d)$ cord pathology occurs predominantly in the dorsal half of the cord, despite the ventral compression; (e) cuneate fascicle changes and anterior horn cell chromatolysis suggest diffuse injury throughout the cervical spine; $(f)$ mechanical deformation, stretch and motion, rather than ischaemia appear to have played the primary part in the pathological changes observed.

Thus, in terms of treatment, (a) widespread subaxial cord involvement with myelopathy may not respond to surgical decompression at the craniocervical junction and $(b)$ focal cord compression due to deformity or instability, even in the relatively asymptomatic patient should be treated surgically before neurological deterioration occurs. 
The authors are grateful to Dr J T Hughes, Dr J M Stevens, Dr B E Kendall, and Professor Alf Breig for their help and encouragement. Dr Fraser C Henderson was sponsored by the United States Navy as the International Spinal Fellow at the National Hospitals for Neurology and Neurosurgery. This work has been supported, in part, by a generous donation from His Highness the Aga Khan. The authors are grateful to Michelle Green for her assistance with the preparation of the manuscript.

1 Smith P H, Benn R T, Sharp J. Natural history of rheumatoid cervical luxations. Ann Rheum Dis 1972; 31: 431-9.

2 Conlon P W, Isdale I C, Rose B S. Rheumatoid arthritis of the cervical spine. An analysis of 33 cases. Ann Rheum Dis 1966; 25: 120-6.

3 Bland J H. Rheumatoid arthritis of the cervical spine. f Rheumatol 1974; 1: 319-41.

4 Nakano K K, Schoene W C, Baker R A, Dawson D M. The cervical myelopathy associated with rheumatoid arthritis: analysis of 32 patients with two postmortem cases. Ann analysis of 32 patients
Neurol $1978 ; 3: 144-51$

5 Menezes A H, van Gilder J C, Clark C R, El-Khoury G. Odontoid upward migration in rheumatoid arthritis. An analysis of 45 patients with cranial settling. $\mathcal{F}$ Neurosurg 1985; 63: 500-9.

6 van Gilder J C, Menezes A H, Dolan K D. The craniovertebral junction and its abnormalities. New York: Futura, 1987: 167-93.

7 Mathews J A. Atlanto-axial subluxation in rheumatoid arthritis. A five year follow up study. Ann Rheum Dis 1974; 33: 526-31.

8 Pellici P M, Ranawat C S, Tsairis, P, Bryan W J. A prospective study of the progression of rheumatoid arthritis of the cervical spine. F Bone foint Surg [Am] 1981; 63: $342-50$

9 Rana N A. Natural history of atlanto-axial subluxation in rheumatoid arthritis. Spine 1989; 14: 1054-6.

10 Marks J S, Sharp J. Rheumatoid cervical myelopathy. Qf Med 1981; 50: 307-19.

11 Crockard H A, Essigman W K, Stevens J M, Pozo J L, Ransford A O, Kendall B E. Surgical treatment of cervical cord compression in rheumatoid arthritis. Ann Rheum Dis 1985; 44: 809-16.

12 Santavirta S, Kakaanpää U, Sandelin J, Laasonen E, Konttinen Y T, Slätis P. Evaluation of patients with Konttinen
rheumatoid cervical spine: a review. Scand $\mathcal{f}$ Rheumatol 1987; 16: 9-16.

13 Agarwal A K, Kraus D R, Eisenbeis C H Jr, Stolzer B L, Balk P M, Barkley T A. Anatomical and neurological characteristics of cervical spine involvement in rheumatoid arthritis. F Orthop Rheumatol 1989; 2: 77-89.

14 Dvorak J, Grob D, Baumgartner H, Gschwend N, Grauer rheumatoid arthritis and instability of upper cervical rheumatoid arthritis and insta
spine. Spine 1989; 14: 1057-64.

15 Papadopoulos S M, Dickman C A, Sonntag V K H Atlantoaxial stabilization in rheumatoid arthritis. 7 Neurosurg 1991; 74: 1-7.

16 Davis F W, Markley H E. Rheumatoid arthritis with death from medullary compression. Ann Intern Med 1951; 35: 451-4.

17 Mikulowski P, Wollheim F A, Rotmil P, Olsen I. Sudden death in rheumatoid arthritis with atlanto-axial dislocation. Acta Med Scand 1975; 198: 445-51.

18 Hughes J T. Spinal cord involvement by C4-C5 vertebral subluxation in rheumatoid arthritis: a description of two cases examined at necropsy. Ann Neurol 1977; 1: cases exan 875 .

19 Ranawat C S, O'Leary P, Pellici P, Tsairis P, Marchisello P, Dorr L. Cervical spine fusion in rheumatoid arthritis. F Bone foint Surg [Am] 1979; 61: 1003-10.

20 Steinbrocker O, Traeger C H, Batterman R C. Therapeutic criteria in rheumatoid arthritis. $\mathscr{A} A M A$ 1949; 140 659-62.

21 Stevens J M, Kendall B E, Crockard H A. The spinal cord in rheumatoid arthritis with clinical myelopathy: a computed myelographic study. I Neurol Neurosurg computed myelographic stud
Psychiatry 1986; 49: 140-51.

22 Geddes J F, Gonzalez A G. Examination of spinal cord in diseases of the craniocervical junction and high cervical diseases of the craniocervical junction

23 Redlund-Johnell I, Pettersson H. Radiographic measurements of the craniovertebral region, designed for evaluation of abnormalities in rheumatoid arthritis. In Redlund-Johnell I, ed. Dislocations of the cervical spine in rheumatoid arthritis. Malmö: University of Lund; 1984 55-67.

24 Crockard H A, Calder I, Ransford A O. One-stage transoral decompression and posterior fixation in rheumatoid atlanto-axial subluxation. $\mathcal{F}$ Bone foint Surg $[\mathrm{Br}]$ 1990; 72 : 682-5.

25 Breig A. Adverse mechanical tension in the central nervous system. New York: Wiley, 1978: 61-83.

26 Shimomura Y, Hukuda S, Mizuno S. Experimental study of ischemic damage to the cervical spinal cord. $\mathcal{F}$ Neurosurg 1968; 28: 565-81.

27 Bedford P D, Bosanquet F D, Russell W R. Degeneration of the spinal cord associated with cervical spondylosis. Lancet $1952 ; 2: 55-9$.
28 Mair W G P, Druckman R. The pathology of spinal cord lesions and their relation to the clinical features in protrusion of cervical intervertebral discs. Brain 1953; 76 $70-91$

29 Wadia N H. Myelopathy complicating congenital atlantoaxial dislocation. Brain 1967; 90: 449-70.

30 Wilkinson $M$. The morbid anatomy of cervical spondylosis and myelopathy. Brain 1960; 83: 589-617.

31 Dastur D K, Wadia N H, Desai A D, Sinh G. Medullospinal compression due to atlanto-axial dislocation and sudden haematomyelia during decompression. Brain 1965; 88: haematomy $897-927$.

32 Ducker T B, Kindt G W, Kempe L G. Pathological findings in acute experimental spinal cord trauma. 7 Neurosurg 1971; 35: 700-8.

33 Tarlov I M. Acute spinal cord compression paralysis. f Neurosurg 1972; 36: 10-20

34 Hughes J T. Pathology of spinal cord damage in spinal injuries. In: Feiring E H, ed. Brock's injuries of the brain and spinal cord. 5th ed. New York: Springer, 1974.

35 Gooding M R, Wilson C B, Hoff J T. Experimental cervical myelopathy. F Neurosurg 1975; 43: 9-17.

36 Balentine J D. Impact injuries of the spine and spinal cord. In: Leestma J E, ed. Forensic neuropathology. New York: Raven Press, 1988: 254-75

37 Elsberg C A, Strauss I. Tumors of the spinal cord which project into the posterior cranial fossa. Arch Neurol Psychiatry 1929; 21: 261-73.

38 Symonds C P, Meadows S P. Compression of the spinal cord in the neighbourhood of the foramen magnum. Brain 1937; 60: 52-84

39 Taylor A R, Aberd M B. Vascular factors in the myelopathy associated with cervical spondylosis. Neurology 1964; 14: $62-8$.

40 Frykholm R. Cervical nerve root compression resulting from disc degeneration and root sleeve fibrosis. Acta Chirurgica Scand 1951; 160 (suppl): 24-33.

41 Brain W R, Northfield D, Wilkinson M. The neurological manifestations of cervical spondylosis. Brain 1952; 75: 187-225.

42 Payne E E, Spillane J D. The cervical spine: an anatomicopathological study of 70 specimens (using a special technique) with particular reference to the problem of cervical spondylosis. Brain 1957; 80: 571-616.

43 Breig A, Turnbull I, Hassler O. Effects of mechanical stresses on the spinal cord in cervical spondylosis. stresses on the spinal cord

44 Spillane J D, Lloyd G H T. The diagnosis of lesions of the spinal cord in association with osteoarthritic disease of the cervical spine. Brain 1952; 75: 177-86.

45 Hoff J, Nishimura M, Pitts L, Vilnis V, Tauerk K, Lagger $R$. The role of ischemia in the pathogenesis of cervical spondylotic myelopathy. Spine 1977; 2: $100-8$.

46 Webb F W S, Hickman J A, Brew S J. Death from vertebral artery thrombosis in rheumatoid arthritis. $B M F$ 1968; 2: $537-8$

47 Hughes J T. Pathology of the spinal cord. 2nd ed. London: Llovd-Luke, 1978: 176-9.

48 Zeitlin H, Lichtenstein B W. Occlusion of the anterior spinal artery. Arch Neurol Psychiatry 1936; 36: 96-111.

49 Hughes J T, Brownell B. Spinal cord ischemia due to arteriosclerosis. Arch Neurol 1966; 15: 189-202.

$50 \mathrm{Kim} \mathrm{R} \mathrm{C,} \mathrm{Collins} \mathrm{G} \mathrm{H.} \mathrm{The} \mathrm{neuropathology} \mathrm{of} \mathrm{rheumatoid}$ disease. Hum Pathol 1981; 12: 8-15.

51 Morrison L R, Short C L, Ludwig A O, Schwab R S. The neuromuscular system in rheumatoid arthritis. $A m \mathrm{~F} \mathrm{Med}$ Sci 1947; 214: 33-9.

52 Morrison L R, Cobb S, Bauer W. The effect of advancing age upon the human spinal cord. Massachusetts: Harvard upon the human spinal cord.

53 Jellinger K. Spinal cord arteriosclerosis and progressive vascular myelopathy. I Neurol Neurosurg Psychiatry 1967; 30: $195-206$.

54 Hughes J T. Venous infarction of the spinal cord. Neurology 1971; 21: 794-800.

55 Taylor A R, Byrnes D P. Foramen magnum and high cervical cord compression. Brain 1974; 97: 473-80.

56 Doppman J L. The mechanism of ischemia in anteroposterior compression of the spinal cord. Invest Radiol 1975; 10: 543-51.

57 Henderson F C, Crockard H A, Stevens J M. Spinal cord oedema due to venous stasis. Neuroradiology 1993; 35: $312-5$.

58 Hukuda S, Wilson C B. Experimental cervical myelopathy: effects of compression and ischemia on the canine cervical effects of compression and ischemia
cord. F Neurosurg 1972; 37: 631-52.

59 Jacobs J A, Lequesne T M. Toxic disorders. In: Adams J H and Duchen L W, eds. Greenfield's neuropathology. 5 th ed. London: Edward Arnold, 1992: 881-91

60 Winderbank A J. Metal neuropathy. In: Dyck P J, Thomas P K eds. Peripheral neuropathy. 3rd ed. London: Saunders, 1993: 1563-6.

61 Yu Y L, Du Boulay G H, Stevens J M, Kendall B E. Computer-assisted myelography in cervical spondylotic myelopathy and radiculopathy. Brain 1986; 109: 259-78.

62 O'Connell J E A. The place of surgery in the treatment of cervical spondylosis. Proc Roy Soc Med 1956; 49: 202-12. 63 Breig A, El-Nadi A F. Biomechanics of the cervical spina cord. Acta Radiol 1966; 4: 602-24.

64 Adams C B T, Logue V. Studies in cervical spondylotic myelopathy. Parts I-III. Brain 1971; 94: 557-94.

65 Smith C G. Changes in length and position of the segments of the spinal cord with changes in posture in the monkey. Radiology 1956; 66: 259-65. 
66 Reid J D. Effects of flexion-extension movements of the head and spine upon the spinal cord and nerve roots. f Neurol Neurosurg Psychiatry 1960; 23: 214-21.

67 Ono K, Ota H, Tada K, Yamamoto T. Cervical myelopathy secondary to multiple spondylotic protrusions. Spine 1977; 2: 109-25.

68 Barnes M P, Saunders M. The effect of cervical mobility on the natural history of cervical spondylotic myelopathy. F Neurol Neurosurg Psychiatry 1984; 47: 17-20.

69 Jellinger K. Neuropathology of cord injuries. In: Vinken $P$ $J$ and Bruyn G W, eds. Handbook of clinical neurology. $\mathrm{J}$ and Bruyn G W, eds. Handbook of clinical neurology.
Vol. 25. Injuries of the spine and spinal cord, part I. Vol. 25. Injuries of the spine and spin

70 Hughes J T, Brownell B. Cervical spondylosis complicated by anterior spinal artery thrombosis. Neurology 1964; 14: 1073-7.

71 Ball J, Sharp J. Rheumatoid arthritis of the cervical spine. In: Hills A G S, ed. Modern trends in rheumatology. London: Butterworth, 1971.

72 Konntinen Y T, Santavirta S, Kauppi M, Moskovich R. The rheumatoid cervical spine. Curr Opin Rheumatol 1991; 3: 429-40.

73 Hopkins J S. Lower cervical rheumatoid subluxation with tetraplegia. $\mathcal{f}$ Bone foint Surg $[\mathrm{Br}] 1967 ; 49$ : 46-50.

74 Eulderink F, Meijers K A E. Pathology of the cervical spine in rheumatoid arthritis: a controlled study of 44 spines. in rheumatoid arthritis: a cont

75 Bland J H, Boushey D R. Anatomy and physiology of the surgical spine. Semin Arthritis Rheum 1990; 20: 1-20.

76 Rogers M A, Crockard H A, Moskovich R, et al. Nystagmus and joint position sensation; their importance in posterio occipito-cervical fusion in rheumatoid arthritis. Spine. In press.
77 Rana N A, Hancock D O, Taylor A R, Hill A G S. Upward translocation of the dens in rheumatoid arthritis. $\mathcal{f}$ Bone foint Surg [Br] 1973; 55: 471-7.

78 Slatis P, Santivirta S, Sandelin J, Konttinen Y T. Cranial subluxation of the odontoid process in rheumatoid arthritis. F Bone foint Surg [Am] 1989; 71: 189-95.

79 Gall E P, Schumacher H R. Systematic features of rheumatoid arthritis. In: Schumacher E P and Gall E P, eds. An illustrated guide to pathology, diagnosis and management. Philadelphia: Lippincott, 1988: 14.78-80.

80 Hunter J V, Stevens J M, Kendall B E, Moskovich R, Crockard H A. Radiological assessment for transoral surgery in rheumatoid arthritis, using dynamic CT surgery in rheumatoid arthritis, using dynamic

81 Crockard H A, Heilman A E, Steven J M. Progressive myelopathy secondary to odontoid fractures: clinical, radiological and surgical features. F Neurosurg 1993; 78: 579-86.

82 Holmes G. On the relation between loss of function and structural change in focal lesions of the central nervous system, with special reference to secondary degeneration. Brain 1906; 29: 514-23.

83 Gledhill R F, Harrison B M, McDonald W I. Demyelination and remyelination after acute spinal cord compression. and remrol 1973; 38: 72 . 87 .

84 Koles K J, Rasminsky M. A computer simulation of conduction in demyelinated nerve fibers. 7 Physiol 1972; 227: $351-64$.

85 Hamblen D L. Postgraduate textbook of clinical orthopaedics. Bristol: Wright, 1983: 487-97.

86 Wilber R G, Thompson G H, Shaffer J W, Brown R H, Nash C L. Post-operative neurological deficits in segmental spinal instrumentation. $\mathcal{F}$ Bone foint Surg [Am] 1984; 66: 1178-87. 